\title{
Historical Type in the Collection of the Plantin-Moretus Museum in Antwerp from a Metal Conservators' Point of View
}

\author{
Patrick Storme
}

\section{ABSTRACT}

From the fifteenth to the eighteenth century, hand presses and movable type were used for book printing. The knowledge of historical lead-based types, from a material point of view, is relatively scarce. The conservation of type in the Museum Plantin-Moretus (Antwerp) drew attention to the corrosive behavior of some types. To investigate the relation between the type compositions and the environment, contemporary literature on type alloying and casting was compared with analytical research on a selection of historical type. As a conclusion, lead alloy compositions with high concentrations of antimony and low tin levels were the most subjected to corrosion and are to be preserved in appropriate conditions.

\section{INTRODUCTION}

The printing of hand-pressed books requires paper, ink and moveable type. In turn, the production of type involves steel punches for each character, which are struck using copper matrices. These matrices were inserted into a mould to cast the type. The Plantin-Moretus Museum in Antwerp is known worldwide for its historical building and its outstanding collection of presses, books, archives, punches, matrices and type. Much of this has been studied extensively, but the lead type was always of lesser interest due to the supremacy of the punches and matrices, which hold without any doubt, the keys to historic typography. Cast lead type is often regarded as only of secondary interest, since it can only be produced via matrices. A question of authenticity is also posed, since the lead type could be recast at any time in history. Regardless of these very important facts that we have to bear in mind, an in-depth study based on the materials used might provide new evidence. In general, handbooks mention lead, tin and antimony as the composite elements of historical type, but little is actually known with certainty about the different metal components used in the fifteenth and sixteenth centuries. This article focuses on the alloy of historical type preserved in the Plantin-Moretus Museum. A methodology and a measuring technique for the alloys are proposed to survey surviv- ing pieces of type. To date, material-based research has not been performed on a larger scale. Today, analytical instruments provide the opportunity to measure large quantities of metal alloys in a relative short period and in a non-destructive way.

Firstly, we will outline the museum's collections and their importance for this survey. This will be followed by an enumeration of contemporary texts that mention alloys used in type: Vannoccio Biringuccio's La pirotechnia (1540), Joseph Moxon's Mechanic Exercises on the Whole Art of Printing (1683) and Pierre-Simon Fournier's Art typographique (two volumes, 1764-1766). Secondly, the information and techniques in these documents will be addressed using two surveys. Walter Wilkes (1990) discussed the characteristics of the different components and those of different alloys by using them in different combinations, while Harry Carter (1960) examined the actual composition of sixteenth-century type present in the Plantin-Moretus Museum. In the final section, the results of a scientific analysis using the non-invasive XRF (X-Ray Fluorescence) technique are presented. This instrument measures the presence and calculates the relative quantity of the different metals in type alloys. It is argued that this technique might provide new evidence. Finally, knowledge about the composition of specific types will help to preserve these valuable objects for future generations.

\section{THE MUSEUM COLLECTION}

The origin of the Museum Plantin-Moretus (Plantin-Moretus Museum) dates from the most important printer-publisher in the second half of the sixteenth century: Christopher Plantin. As the first 'industrial' printer, he proved to be a genius autodidact and a pioneer in the history of book printing, second only to Johannes Gutenberg. His exceptional legacy of publications on humanism and the sciences is still regarded as being of utmost importance for western civilisation. Today, the museum still houses magnificent sixteenth- and seventeenth-century Renaissance rooms and a courtyard as memorabilia of bygone centuries of delicate 
luxury and wealth. However, the primary interest in terms of the history of typography are the 'Officina', the casting room, the letter room, the print shop, the correctors' room, the bookshop and the office of the printer-publisher. In addition to these magnificent historical settings there are the typographic collections with the oldest printing presses, punches, matrices, type, drawings, woodblocks, copper plates and related materials and tools.

The collection of type is internationally renowned. Some of the rarest standing types are exhibited, including texts in Latin, Greek, Hebrew, Chaldean and even Ethiopian. As indicated by the type specimens ('letterproeven'), we know that Plantin had over 90 different typefaces. He also managed to create large material inventories; thus, his successors only had to provide new fonts. Plantin bought his material from the best Flemish and French specialists of his time with a level of concern for integrated quality levels that was unprecedented. He always looked to the best to print certain works, independent of what was available in Antwerp. The print shop therefore holds a large number of punches and matrices, originating from the most important letter-cutters and designers of the sixteenth century. Today, the museum contains approximately 4,500 punches, almost 16 , ooo matrices and 62 type-founders' moulds, representing 9o letter series such as Roman, Italic, Gothic and Civilité, as well as music notation, Hebrew, Greek and Syrian. Many revivals of these fonts are still found in the typography of today.

\section{RESEARCH}

For the optimum preservation of this important collection, it is necessary to understand the materials of which the components are made: steel punches, copper matrices, a combination of metals and wood for the type-founders' moulds and lead-based alloy type. The reason for analytical research on a portion of the type collection was the occurrence of the severe corrosion of some of the lead type, which was kept in the original wooden trays used at the time of the active printing house. Unlike at the time when they were on use, the type has been resting for decades in the trays, closed with a hardboard lid for protection against the environment, mixing up, loss or theft. However, this led to the corrosion of some of the type, as was recently discovered by the museum staff. A first approach to the problem was a small-scaled research project by the conservation department of the Royal Academy of Fine Arts in Antwerp. ${ }^{1}$ It became clear that the source of the corrosion was a combination of environmental parameters and the composition of the lead type alloys.

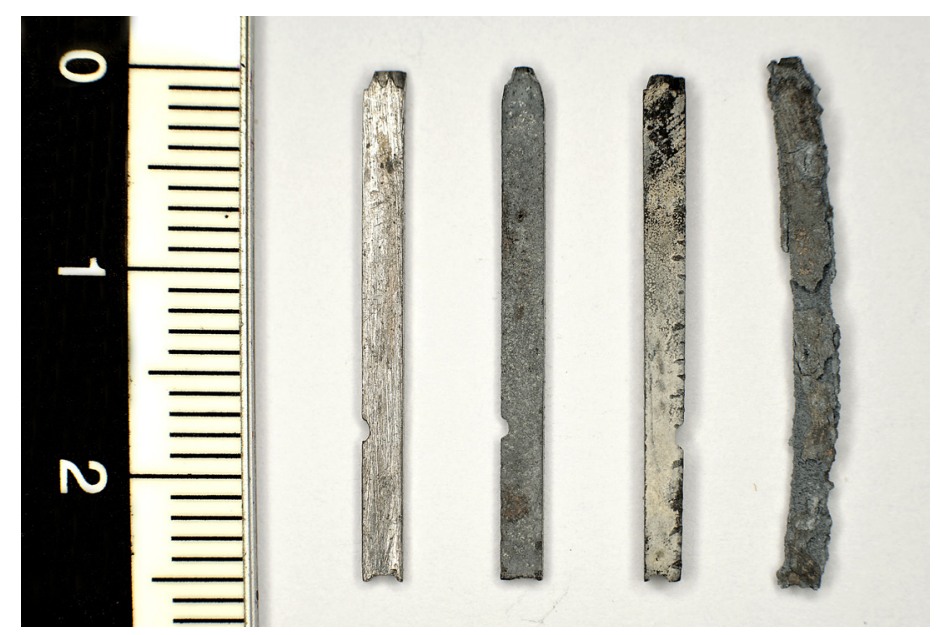

Figure 1. Four types from left to right: without corrosion; with an even dark grey corrosion; with a dense white layer of passive corrosion and finally an example of a vigorously corroded item that has lost all structural rigidity, form and readability.

The environmental conditions in the historical museum are not favourable for lead based alloys. Antwerp and its port close to the city centre engage in large-scale industrial activities, contributing to Flanders being one of the most polluted areas in Europe. Although emissions of $\mathrm{SO}_{2-}, \mathrm{NOx}\left(\mathrm{NO}_{2}\right)_{-}$ and $\mathrm{CO}_{2}$ have diminished over the last decade, ${ }^{2}$ it cannot be denied that these pollutants could have contributed to the air pollution in general and to the museum's environment in particular. It is also known that acidic atmospheres promote lead corrosion. Because of the abundance of oak in the building's floors, beams and windows, as well as in the furniture, presses and trays, high levels of acids were measured. ${ }^{3}$ In addition to the occurrence of acidic gasses in the indoor environment, a relative humidity level (RH) of about $55 \%$ must be maintained for the preservation of the building and all the wooden artefacts within it. For metal conservation, however, this RH is somewhat high and promotes ion exchanges between the metal and its surroundings, resulting in corrosion.

According to the literature, type is mainly coposed of lead $(\mathrm{Pb})$, with additions of antimony $(\mathrm{Sb})$, tin $(\mathrm{Sn})$ and, in some cases copper $(\mathrm{Cu})$, with traces of iron $(\mathrm{Fe})$ or other metals. In the early days of printing, however, it is thought that tin was the main element ${ }^{4}$ and that lead and antimony were the alloying elements, together with small concentrations of copper and iron that were included accidently or deliberately. Since there are no systematic records regarding the composition of the type in the Plantin-Moretus Museum, an analytical method had to be applied. Out of consideration for the historical value and the vast number of types in the collection, the preferred method had to be nondestructive, quick and applicable in situ. Because of these requirements, X-ray Fluorescence (XRF) was chosen. A handheld XRF instrument is able to 
detect the constituent elements in any metal alloy within minutes.

\section{EARLY TYPE ALLOY COMPOSITIONS}

There is little knowledge about the very first alloys that were used for casting type in the mid-fifteenth century. We do know, however, that the reproduction and casting techniques were derived directly from the art of goldsmithing and the related art of the pewterer. It is known that Gutenberg was involved in the mass production of pilgrim badges before he developed (or is alleged to have developed) movable print. The direct and causal relationship between these two forms of culturally important mass production items has already been mentioned. 5 A copper die-piece in the British Museum showing the surviving half of a Wheel of Fortune was proved to have been used for the production of identical brooches in precious metal. ${ }^{6}$ An identical pewter fragment held in Zierikzee is a cheap cast version, probably made using the same English die-piece.

Insignia, pilgrims' badges or other religious and secular badges were very common in the early Middle Ages. They were usually cast in lead-tin alloys because this material was relatively cheap and very easy to produce in large quantities. These alloys produced pieces with extremely fine details, leaving us many surviving examples from the fourteenth and fifteenth centuries.7 The most commonly used technique was casting, although stamping or pressing could also have been used, with or without a heating technique for openwork pieces. How the prototype was formed and what kind of casting mould was used varied from engraved slate laid over clay and plaster to sand or bronze counter forms. Van Beuningen described the techniques used and the composition of fifty badges in his collection. Analyses have revealed that one example consists of $95.9 \%$ lead, $2.6 \%$ tin and $1.4 \%$ arsenic. The latter was attributed to pollution. Thirty-seven other pieces had higher tin contents, between $35 \%$ and $65 \%{ }^{8}$ Many brooches were decorated with text or, in some cases, were merely decorated letters themselves. Given this existing tradition, it is understandable and highly likely that this technology was transferred to the printing process with movable type attributed to Gutenberg.

The type founding, as practiced in Europe and the West, consists in its fully developed form of three stages: punch cutting, the making of matrices and the actual casting of the printing letters in hand moulds, holding the specific matrix.9 Punches are made out of steel and hardened after finishing the typeface. This punch is driven into a blank rod of soft copper, leaving the negative imprint of the punch. This matrix is placed into a hand mould that has the correct dimensions for the body shank and the break height.

\section{TYPE ALLOY COMPOSITION IN THE SIXTEENTH TO EIGHTEENTH CENTURIES}

There is little knowledge about the very first alloys Literature from the early days of printing on the technical aspects of type alloys and casting is relatively scarce. Some information that is relevant to this article is taken from the well-known sources of Biringuccio, Moxon and Fournier, and complemented by extracts from publications by Voet. The first text to disclose some of the knowledge about printing type and its alloys is found in the treatise La Pirotechnia by Vannoccio Biringuccio, published in 1540 just after his death. ${ }^{10}$ The content of this book was collected in the first quarter of the sixteenth century and is the oldest known source of information on the topic. Biringuccio had the opportunity to travel through Italy and to Germany during his early years. In the text, he indicated that he visited Friuli and Carnia in Northern Italy in 1507 , after having travelled in Germany. ${ }^{.1}$ It appears that Biringuccio made a second trip to Germany between 1526 and $1529 .{ }^{12}$ In 'The Seventh Chapter, Concerning the Art of the Pewterer', Biringuccio referred to 'the art of making the letters with which books are printed, and the other is that of making the sheets from which organ pipes are built.' He continued, 'The letters for printing books are made of a composition of three parts of fine tin, an eighth part of black lead, and another eighth part of fused marcasite of antimony.' In 'The Third Chapter, Concerning Antimony and Its Ore', Biringuccio mentioned that

from Germany they bring to Venice some of the smelted kind in cakes for the use of those masters who make bells, because they find that by mixing a certain part of it with the metal the sound is greatly increased. Those who make pewter vessels also use it as do those who make mirrors both of glass and of a special composition of metals.

It is known that the addition of metals that harden the alloy gives the bells a clearer sound. When metallic mirrors are produced, the addition of antimony can increase the hardness of the lead-tin alloy significantly, which makes it much brighter and easier to polish to a high gloss finish to produce accurate reflections. As Gutenberg was also involved in the mass production of pilgrims' mir- 
rors, he might have used this knowledge when manufacturing type, although there is no evidence for this. Unlike the wear and tear that occurs on type used for printing, pilgrim signs or mirrors do not experience wear to the same extent and could also be used and maintained easily without antimony in their alloy composition. Moreover, a precise date for the introduction of antimony in the fifteenth century cannot be given.

Moxon (seventeenth century, England) opened his 'Preface' with the description of different terms and working conditions. The first hierarchy entailed the distinction between the master printer, who was ranked first and the lesser workers, who were ranked as follows:
2) The letter-cutter
3) The letter-caster,
4) The letter-dresser

(these three trades were grouped into a category called the 'Founders'),
5) The compositor,
6) The corrector,
7) The press-man, and
8) The ink-maker

(the latter four were grouped as 'Printers').

Supporting trades included black- or coppersmiths, joiners (woodworkers), amongst others.

Chapter 2, 'Of the Office of a Master-Printer', focuses on the terminology used by printers. One important name is 'The Printing House'. This could mean the house in which the tools were physically present and where the printer executed the work. On the other hand, a 'Printing House' could also refer to the collection of tools needed for all aspects of the printing trade. Therefore, it was possible to remove a 'Printing House' from a building, meaning that only the printing tools were removed.

Moxon further stated that taking care in choice of appropriate letters relies on four aspects: 1) That the Letter has a true shape, 2) That they be deep cut; 'for then they will Print clear the longer, and be less subject to entertain Picks', 3) That they be deep sunk in the matrices and ${ }_{4}$ ) 'That his Letter be cast upon good Mettal, that it may last the longer.'

This 'Mettal' being addressed in chapter 18 , §2: 'Of Making Mettal', which suggests that it is lead hardened with iron. To make the iron fluid, an equal weight of antimony and stub nails (soft but tough iron) is melted together. A long and detailed explanation regarding exactly these metals should be melted and poured together is provided, showing that the process was extremely difficult and was vulnerable to mistakes or mishaps. Here, only the ratios of the composition of the alloys are considered. Moxon provided the example of preparing five melting pots, each able to contain between forty and fifty pounds, for which a new brick furnace was built. These melting pots were filled to the brim with equal weights of iron and antimony pieces. These metals were melted until the workers heard 'bubbling', whereafter they continued to heat the fire to ensure that all the metal was molten and homogenised. When molten, not a quarter of each melting pot was filled; in other words, each pot contained about 10 pounds of the alloy, consisting of $50 \%$ iron $(\mathrm{Fe})$ and $50 \%$ antimony $(\mathrm{Sb})$. Another furnace was built alongside the first for the iron melting pots containing the lead. A ratio of 'about five and twenty pounds of Lead is taken for every three Pound of Iron.' This seems to be only a directive regarding how much lead must be provided to be melted and to proceed with the manufacture. When all the metals were in a molten state, lead was poured into each of the melting pots holding the iron and antimony alloy until they were full. Thus, between thirty and forty pounds of $\mathrm{Pb}$ was added to the ten pounds of $\mathrm{Fe}-\mathrm{Sb}$ alloy, resulting in a composition of between $\mathrm{Pb}-\mathrm{Sb}-\mathrm{Fe}$ 80.0-10.0-10.0 and 75.0-12.5-12.5, without taking losses due to oxidation or evaporation into account.

Fournier (eighteenth century, France) also provided a complete chapter on the composition of the alloys in his publication. ${ }^{13}$ The chapter 'Du métal servant aux caractères' first discusses the overall composition. In a subsequent chapter, he focused on antimony, which he called 'Le régule'.

The alloy, used for casting letters, is a composition designed specifically for this purpose and is used for nothing else. Lead is the base, which can be reinforced or hardened by adding other metals or mineral ores. This is called matter ('la matière'), and a distinction is made between strong matter ('matière forte') and weak matter ('matière faible'). This matter usually consisted of lead, crude copper ('potin') and sometimes iron: the latter were melted separately from the lead with antimony and were then added. This was very difficult and dangerous work (as Moxon also described) and only produced imperfect material. The flow was greasy and thick, and caused problems when being heated in the melting pan because it formed thick, hard crusts on the melt, which sometimes accounted for up to a fifth or sixth part of the complete melt.

It appears that, from the beginning of the eighteenth century, the work was simplified and enhanced by simply using lead and antimony ('de régule d'antimoine'). 'Le régule' is antimony that is refined from its ore by removing earth parts, sulphur and salts, by reducing it on a fire until only bright metal parts remain. The ratio of antimony in 
Cost/10o pounds 1565 Antwerp 1760 Antwerp

\begin{tabular}{lll}
\hline Lead $(\mathrm{Pb})$ & 3 fl. 18 st. & 6 fl. 9 st. \\
\hline Old lead $(\mathrm{Pb}+\mathrm{Sn} ?)$ & & 9 fl. o st. \\
\hline Antimony $(\mathrm{Sb})$ & 5. fl. 8 st. & $14-16$ fl. o-6 st. \\
\hline Tin $(\mathrm{Sn})$ & 15 fl. 10 st. & \\
\hline Copper $(\mathrm{Cu})$ & 17 fl. 10 st. & \\
\hline Iron $(\mathrm{Fe})$ & 2 fl. 10 st. & $1 \mathrm{fl} 15 \mathrm{st}$.
\end{tabular}

Figure 2: Cost of metal for composing type metal alloys. ${ }^{14}$ Intrinsic value of the florin (fl.) declines between 1565 and 1760 roughly from 100 to $40 . .^{15}$

the alloy was fifteen, twenty or twenty-five pounds ('livres') to a hundred pounds of lead. In weight per cent, this produced alloys containing $13.0 \%, 16.6 \%$ and $20.0 \%$ of antimony, respectively. The three alloys were called weak, medium and strong matter. The highest content of antimony was used for the smaller letters, such as 'Nompareille' and 'de Mignonne ou Petit-texte'. The respective melting points of the above-mentioned alloys are $275^{\circ} \mathrm{C}$, $295^{\circ} \mathrm{C}$ and $330^{\circ} \mathrm{C}$. The main reason for adding more antimony to cast smaller types was the lower viscosity of the high Sb-alloy, in addition to greater hardness. Fournier further stated that old lead was preferred to new, because it is 'more purified and harder'. New lead, such as that mined recently (in other words, in the mid-eighteenth century) in Bretagne was much too soft for this kind of use. Old lead may also contain some tin or other metals, making it harder. However, this is in contradiction to Fournier's opinion that it is 'more purified'. Lead that was reinforced and hardened by the use of 'Régule' resulted in a metal that was dry and brittle. A few strokes of a hammer on an anvil broke it into pieces easily. The fracture surface consists of fine, shiny grains. Melting antimony and lead together produced an alloy with a lower melting point than that of lead itself, according to Fournier, 'because it is more porous and enables the heat to access more easily.' The metal lost weight and decreased in quality due to oxidation formation on the melt, which had to be removed every time a new scoop was taken for casting.

Fournier addressed the preparation and use of antimony separately. He stated that the exact use and composition for the casting of letters had been a secret for a long time, but because now the alloy was currently composed of lead and antimony, he had decided to describe it clearly in his work. The chemistry of the time only suggested procedures for refining the metal in small amounts, which was impractical for commercial printing. Only one or two people in Paris were able to deliver the antimony to every user in France, which made it a costly metal. Fournier himself developed the necessary tools and workflow at Orléans to refine his own antimony.

Earlier research on this topic, conducted by Leon Voet in the 1960 s and 1970 os, also investigated the technical aspects of the letter founding at Plantin-Moretus, Antwerp. ${ }^{16}$ This publication derived detailed information from the archives of the Plantin-Moretus Museum. Sixteenth-century records were researched for information on all aspects of Plantin's printing trade. Voet opened the chapter 'The Printer's Techniques and Methods' with a discussion of the moulds and their value to the market. With regard to the alloy composition of the type, Voet referred to Carter, in which some analyses of letters from the collection of the Plantin-Moretus Museum were conducted. ${ }^{17}$

It can be concluded from the archives that Plantin used various terms to describe the different qualities of casting alloys, namely simply 'estoffe' or 'matière' on one hand and 'estoffe' or 'matière dure' or 'forte' on the other, without further elucidation. Voet assumed that the 'estoffe dure' was made almost exclusively using a lead base with a strong concentration of antimony (in other words, without the separate addition of tin), whereas tin was added to the 'estoffe'. He quoted extracts from the archives to support this view. ${ }^{18}$ A text dated 1565 actually states how much of each ingredient Plantin needed to produce a given quantity of type metal, namely 493 pounds of lead $(63.8 \%), 155$ pounds of antimony (20.0\%), 100 pounds of tin (12.8\%) and 25 pounds of copper $(3.4 \%)$, giving a total of 773 pounds. However, from this amount, only 517 pounds of usable type metal could be made, which means that about one third was lost or expelled during smelting. This was stated by Plantin himself in 1575 when expressing his surprise to Hendrik van den Keere, who prepared type on commission. Of the 3027.25 pounds of metal Plantin delivered, he received only 2713.50 pounds of type. The amount of waste material - the lycagie as it was termed - was much larger when iron scrap was added to the molten metal. In the eighteenth century, Moretus noted that most of this iron, together with a considerable portion of the antimony, was lost during smelting. This was recorded in a Memorandum by Jan Michiel Smit. Smit's proportions for the preparation of type metal included old type that comprised half of the mixture to obtain good results: 50 pounds of old type (30.5\%), 50 pounds of lead (30.5\%), 40 pounds of antimony (24.4\%) and 24 pounds of iron scrap (14.6\%). In addition, compositions written down by Moretus himself show the lack of tin and copper, which were very 
expensive at the time (see Figure 2). It has to be noted, however, that a certain amount of tin can be present in a batch of 'old type' or 'old lead'. The latter may consist completely or partially of lead came soldering points as mentioned in the archive notes, dated October 1563 . These state that the printer bought $35^{1}$ pounds of 'knoppen ou neuds de vieilles verrières à faire estoffe pour fon-der lectres', 125 pounds of antimony 'pour faire l'estoffe dure à fondre', 47 pounds of 'estain d'Oostland (tin from Germany) pour faire matière à lectres', zo pounds of iron filings, 25 pounds of copper filings, melting crucibles, pots and so on. It is noteworthy that lead cames for stained-glass windows were also reused for the same purpose, although the soldering joints (knots and crossings of cames) had to be left out and could be sold for letter casting.

Melting down had been customary from very early times. From about 1565 , melting down old lead and alloys must have been a regular practice, based on the Plantin's archives. ${ }^{19}$ Moretus tried to maintain the levels of tin and copper by melting old type from Plantin's period but, after some time, the amounts of tin and copper became so low that they had little functionality in the alloy. What has been preserved from Plantin's time consists mainly of exotic alphabets that were used only rarely and were almost never recast.

It is clear that sixteenth-century alloys (in Antwerp) consisted of lead (Pb), antimony (Sb), tin $(\mathrm{Sn})$, copper $(\mathrm{Cu})$ and iron $(\mathrm{Fe})$, changing to the use of $\mathrm{Pb}$-Sb-Fe alloys (in seventeenth-century England, as described by Moxon). In England towards the eighteenth century, there was a tendency to use only $\mathrm{Pb}-\mathrm{Sb}$ alloys (Fournier ${ }^{20}$ ) with very small amounts of $\mathrm{Sn}, \mathrm{Cu}$ and $\mathrm{Fe}$ because of the high prices of tin and copper.

\section{TYPE ALLOY COMPOSITION VARIABLES AND THEIR RELATIONSHIP TO CASTING ABILITY AND HARDNESS}

Walter Wilkes published an elaborate work on all the technical aspects of the letter forming and casting processes. ${ }^{21} \mathrm{~W}$ ith regard to the composition of the casting alloys, an overview is provided from metallurgical perspective. For casting of letters, it is desirable that a larger amount of tin-antimony crystals be present in the alloy because of their hardness. An alloy of 79-15-6 Pb-Sb-Sn has a lower melting point, but is harder than is a binary alloy of 85-15 Pb-Sb. On the other hand, due to cost-benefit reasons, there are limits to these additions; moreover, there are technical specifications that demand specific alloy properties for certain nineteenth- and twentieth-century casting machines. Examples containing up to $28 \% \mathrm{Sb}$ and $5 \% \mathrm{Sn}$ are mentioned. This alloy is also the standard DIN 16512 composition for the casting of letters. In this composition, a combination of tin and antimony crystals is found next to pure antimony grains in the eutectic matrix. The segregation of tin-antimony crystals is often a problem, both in the melting pan itself and in the cooling of a cast piece. Antimony always has a tendency to rise to the surface where it oxidises and combines with other oxidation products, rendering it unusable and lost. With regard to the testing of alloys, the letter caster knew from experience whether the alloy was good or bad. He listened to the alloy while breaking a sample piece. This should break easily with a soft bang, and the broken surface should appear silvery grey and finely grained, just as cast iron does. Furthermore, testing with a knife produces a certain sound and the chip that comes off tells the worker whether it is still a good alloy. In 'critical' circumstances, chemical analyses are used. We can assume that the tests involving breaking sounds and chipping with a knife to evaluate the quality of an alloy composition were used in previous centuries. It is should also be noted that bell founders and bronze casters used a similar method by giving a strong hammer blow to a bronze ingot. Hardness, grain structure, grain distribution and grain dimensions, together with porosity or inclusions, are easily observed in this way.

With regard to the older use of alloys for the casting of letters, Wilkes wrote the following from two publications, in 1867 and 1874 respectively, a time when hand casting was a widespread practice and the first automatic casting machines were novelties. ${ }^{22}$ The most common alloy in use at the time was $75 \%$ lead and $25 \%$ antimony regulus, together 'with some pounds' of tin. 'The more pure the metals are, the better the alloy will become.' Concerning the quality of antimony, it was said that the English kind was the best, in contrast to the so-called Westphalian, because it contained some percentage of zinc. Hermann Smalian listed the following composition: 75 pounds of lead, 23 pounds of antimony and two pounds of tin. At that time, tin was included in small quantities because of its price. If the cost of lead were assigned the figure of $100 \%$, then antimony would have had the value of $400 \%$ and tin of $1,000 \%$.

In the chapter on historical compositions for hand casting, Moxon, $\mathrm{Krebs}^{23}$ and Fournier were cited, but no new information on compositions was presented. It is questionable whether the formerly used iron could deliver the desired hardness, or if the hardness was lost due to oxidation and poor mix qualities in the lead-antimony alloy.

The hardening effect of antimony in type alloys is unquestioned. However, many texts mention that the addition of antimony resulted in an expansion 
upon solidification of the alloy in the matrix thus ensuring the most accurate reproduction of the cast letter possible. It is also true that antimony shows an expansion on solidification from the liquid state, as do bismuth and water. In type alloys however, no sufficient amount of antimony is present to create this effect. At least $75 \%$ of antimony should be present with the lead or lead-tin to have this effect. ${ }^{24}$ These high concentrations are never found in type metals, since they would be too brittle. Moreover, the melting point of these alloys (about $600^{\circ} \mathrm{C}$ ) would be too hot to handle and to cast in the copper matrices. Furthermore, such high temperatures would promote the oxidation of the copper matrices, leading to a possible loss of letterform accuracy. As a result, type metals with low antimony concentrations do retract, but to a lesser extent than do pure lead or lead-tin alloys. An average of $2 \%$ is measured and, on the level of type dimensions, this shrinkage can be ignored. The largest benefit is its very low surface tension and low viscosity. These physical facts ensure the caster will have accurate reproductions of the letters from the matrices.

Hardness, as a mechanical property, is determined using a Brinell or a Vickers testing method. Pure lead has a hardness value of approximately Brinell 7 . Adding $16 \%$ of tin to the lead increases the hardness to about Brinell 10, a gain of almost $45 \%$. The addition of $10-15 \%$ antimony to lead increases the hardness values from Brinell 7 to 17 , almost $250 \%$ of the initial lead hardness. When $8 \%$ of tin is added to a $15 \%$ antimony alloy, the hardness value is increased further to Brinell 22 , or $315 \%$ of that of pure lead. When $2 \%$ of copper is also added to a lead (62\%)- antimony (25\%)- tin (12\%) alloy, a Brinell hardness of 35 can be reached, which means the alloy is seven times harder than lead. ${ }^{25}$ Some examples of type alloys are presented in Figure 3, showing the high proportion of antimony particles in the lead matrix.

\section{THE CASTING OF TYPE}

Moxon provided details of this aspect in chapter 1: 'Of Casting, Breaking, Rubbing, Kerning, and Setting Up of Letters':

The caster first must kindle the fire of coals before putting on the melting pan with the Mettal. He should consider whether to cast small bodied letters, the fire must be very hot, sometimes red-hot to make the Letter come. Taking the casting spoon, he strikes a few times the surface of the molten alloy to break the oxidation film on the surface and he can take some pure molten alloy to fill the spoon. Casting this content into the mould, he shakes at the same time the mould for the fluid metal to fill it completely up to the face of the letter in the matrice. The Mettal cools down almost immediately, so it can be thrown out of the opened mould onto sheets of waste paper which are put on the bench for this purpose. If the letter is small, it requires a harder shake than a great body letter does. In some cases, it is so difficult to cast a sharp small letter that the caster is forced to put a little block of tin into his Mettal, which makes it thinner and consequently has a freer flux to the Face of the Matrice. This however changes the composition of the Mettal. He closes the mould again and gets onto a new cast. ${ }^{26}$

Moxon stated that a worker could usually cast about four thousands of these letters in one day.

Fournier (eighteenth century, France) described the same workflow mentioned by Moxon, namely the cutting of the punches ('Taille des poinçoins'), the making of the matrices ('De la frappe des matrices') and the casting ('De la fonte des caracteres'). ${ }^{27}$ The chapter on casting ('Précis de la fonte des caractères') describes the cast-iron melting pan, which was divided into two or three parts. This division allowed different alloys to be melted ('différens degrés de force') and for several workers to be positioned around the furnace. (It must be noted that the use of such a divided melting pan also contributed to inaccurate alloy composition due to spillage while in use). The heat could be turned up or down, according to the requirements of the casting work. The fluid metal was taken up using a spoon and was cast into the ingot of the mould, after which the mould was lifted abruptly upwards ('relève brusquement'), allowing the metal to flow completely into the face of the letter in the matrices below. The mould was then turned and opened to allow the cast letter to be ejected ('crochets'). This was done two to three thousand times a day.

Fournier also addressed the problem of the poor casting of the smaller types ('mal venir'). In addition to controlling the heat of the fire under the melting pan, the method of casting and the movement of the mould should be adapted to obtain better results. Casting the metal while holding the mould at a certain angle and/or casting in a certain corner of the mould ingot should all improve the running of the metal onto the face of the letter in the matrices. However, large letters also sometimes proved to be difficult or impossible to cast cleanly, and the previously mentioned tips had no effect. In these cases, he recommended taking a pumice stone ('pierre-ponce'), grinding it to a 

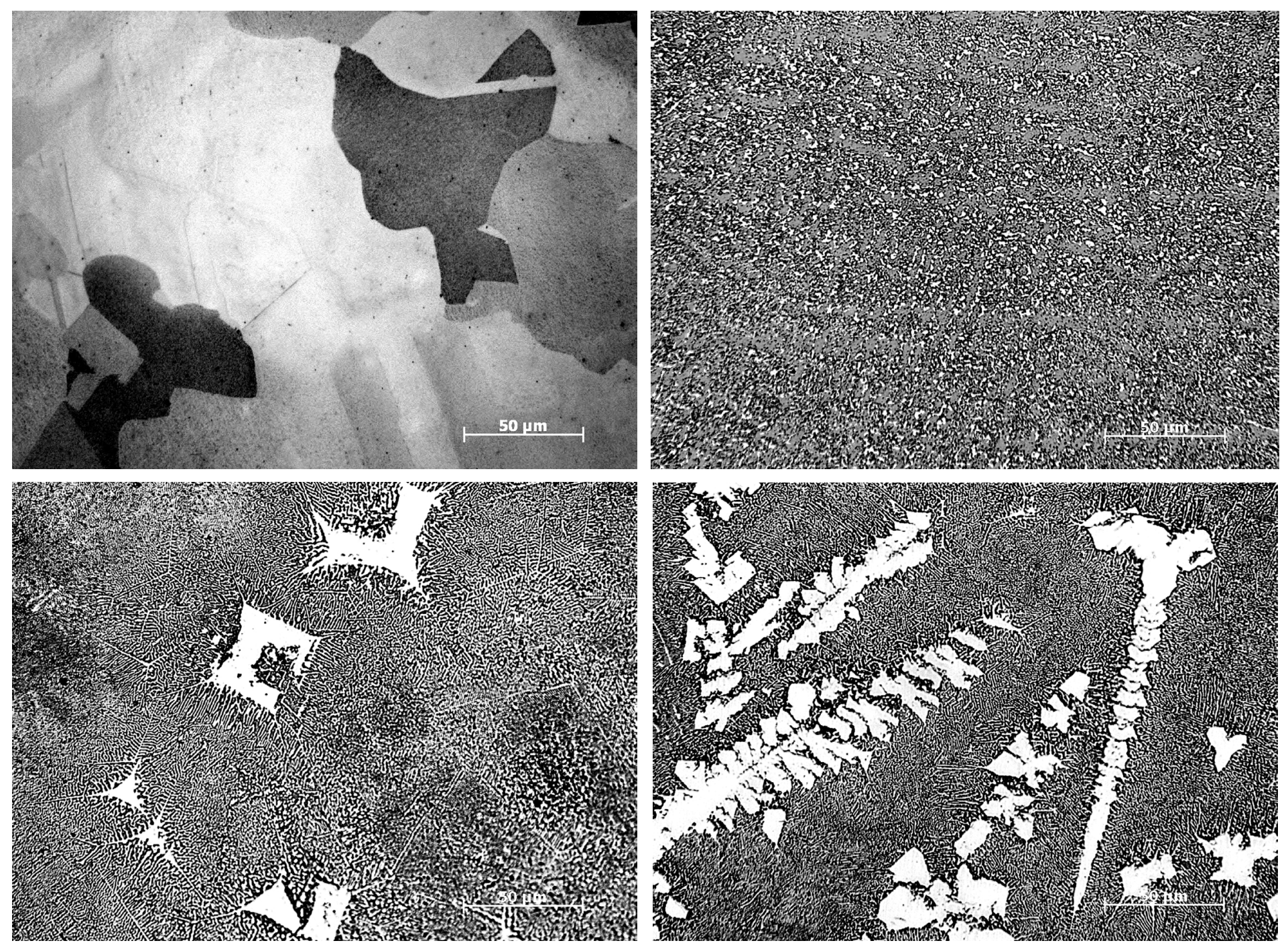

Figure 3: Microscopic images of type alloys, all 5oox magnification; a) Pure lead; b) Lead-Antimony-Tin 8o-8-12 \%; c)

Lead-Antimony-Tin 76-12-12 \%; d) Lead-Antimony-Tin 72-16-12 \%.

very fine powder, putting it into a folded cloth and making a kind of bag. This was then used to dust the ingot, leaving a whitish layer. It was found this enabled the metal to be ejected more easily and produced a sharply cast letter. It is likely that this fine dust layer diminished the effect of the temperature shock between the liquid metal and the ingot; however, this is only a hypothesis.

The primary requirement of good type metal is that it produces good castings under the conditions of operation. Desirable features are hardness, strength, resistance to compression and wear, but all these are secondary in importance to the "casting properties'. ${ }^{28}$ As mentioned in the comments about antimony, the reduction of surface tension is an extremely important factor in obtaining precise castings. Another beneficial property is a low melting point, which is easier and cheaper to maintain in the melting pot, as well as promoting a better flow and slightly slower solidification in the mould. The slow solidification in the mould enabled 'the throw', as described in Moxon and Fournier, which ensured accurate reproductions of the matrices. Even when this may have been only a fraction of a second for smaller letters, it could still make the difference between a good and a bad casting.

\section{TYPE COMPOSITIONS IN THE COLLECTION OF THE MUSEUM PLANTIN-MORETUS}

Carter and Pelgen provided an analysis of Antwerp Plantinian lead type from about 1581 , recording $82.71 \% \mathrm{~Pb}, 5.81 \% \mathrm{Sb}, 8.99 \% \mathrm{Sn}, 0.53 \% \mathrm{Cu}$ and traces of $\mathrm{Fe}^{29}$ It should be questioned if these letters are actually from that period, if they are from a later cast using older matrices, or even if new matrices were made later using original punches. Based on the literature discussed above, a drop in tin and a rise in antimony is to be expected from the sixteenth to the eighteenth century.

Preliminary analyses of a selection of early type from the Plantin-Moretus Museum collection using $\mathrm{XRF}$ analysis show that this non-invasive technique has a certain potential for determining the alloy. Since it is not possible to date the lead alloys in this way, only the ratios of the alloyed elements could give some indication of possible production dates when observations in the literature are taken 


\begin{tabular}{|c|c|c|c|c|c|c|c|}
\hline Inv. & Cutter & Date & Name & Old corpus name & $\mathrm{N}^{\mathrm{o}}$ punch & $\mathrm{N}^{\mathrm{o}}$ matrice & Type $\mathrm{N}^{\mathrm{o}}$ \\
\hline $\mathrm{ET}_{1}$ & $\begin{array}{l}\text { Unknown } \\
\text { (Hand B) }\end{array}$ & $1591-1597$ & Ethiopian & Text $(142 \mathrm{~mm})$ & $\mathrm{ET}_{59}$ & $\mathrm{MA}_{73 \mathrm{a}}$ & $1-5$ \\
\hline $\mathrm{H}_{2}$ & Unknown & 1564 & Hebrew & Double Augustine (120 mm) & & $\mathrm{MA}_{34}$ & 1,2 \\
\hline $\mathrm{FL}_{3}$ & $\begin{array}{l}\text { Van den } \\
\text { Keere }\end{array}$ & $1574-1578$ & Fleuron & $\begin{array}{l}2 \text { regelen } \\
\text { Mediaan }\end{array}$ & $\mathrm{ST} 76 \mathrm{~b}$ & MA188b & 1 \\
\hline $\mathrm{FL}_{3}$ & $\begin{array}{l}\text { Van den } \\
\text { Keere }\end{array}$ & 1574 & Fleuron & Parangon & ST $76 \mathrm{c}$ & MA $188 d, e$ & 2 \\
\hline $\mathrm{FL}_{3}$ & Granjon & 1567 & Fleuron & Text & & MA $188 f, g$ & 3 \\
\hline $\mathrm{FL}_{3}$ & Granjon & $16^{\text {th }} \mathrm{C}$ & Fleuron & Philosophie & & & 4,5 \\
\hline $\mathrm{MU}_{3}$ & $\begin{array}{l}\text { Van den } \\
\text { Keere }\end{array}$ & 1573 & \multicolumn{2}{|c|}{$\begin{array}{l}\text { Petites notes pour les } \\
\text { processionales }\end{array}$} & ST66 & MA 88 & $1-5$ \\
\hline MU6 & $\begin{array}{l}\text { Van den } \\
\text { Keere }\end{array}$ & 1571 & \multicolumn{2}{|c|}{ Moyennes Notes du Missel } & ST65 & MA 87 & $1-5$ \\
\hline MU9 & $\begin{array}{l}\text { Van den } \\
\text { Keere }\end{array}$ & $1577-1578$ & \multicolumn{2}{|c|}{ Moyennes musique } & $\mathrm{ST}_{70}$ & $\mathrm{MA}_{100}$ & $1-5$ \\
\hline
\end{tabular}

Figure 4: Selected type for XRF measurements on the alloy compositions.

into account. The analytical instrument is a small tabletop device that can be operated easily in the museum. It measures the composition of any metal alloy in less than one minute. By conducting X-rays of the sample, ionisation is promoted and the electrons of each specific element emit radiation in turn, which is measured by a detector. This produces a spectrum wherein each element has a specific position on the X-axis (see Figure 5). Because of technical facts associated with the analytical technique, not all peaks in the spectrum can be attributed to certain elements. It is, however, beyond of the scope of this article to specify these features in detail.

Using this spectrum, a software programme measures the peak surface areas and calculates the percentages of the metals present in the alloy. The values are expressed in weight per cent (w\%), normalised to $100 \%$ for the total alloy. Since the concentrations of each element are not determined directly with this technique but are retrieved from a spectrum, it is called a semi-quantitative analytical technique. Therefore, it is not as accurate as other chemical analyses may be, such as Inductive Coupled Plasma Spectrometry (ICP). To enhance the accuracy of the data received from the instrument and the software programme, a large number of measurements were taken from certified lead-antimony-tin alloys. Comparison of the nominal values of these alloys with the results obtained from the XRF led to an accuracy of elemental concentration level within a maximum deviation range of $1 \mathrm{w} \%$. Furthermore, since it is a non-invasive technique, the fact that it provides information from the top layer of the sample, not from the inner bulk core, must be taken into account. However, additional measurements using sacrificed historical type and newly made dummies showed that the deviation of results was never higher than about $2 \mathrm{w} \%$. Despite these drawbacks and the fact that trace elements (less than $0.1 \mathrm{w} \%$ ) are also not recorded, the instrument serves as a highly useful tool for the estimation of alloyed groups and the determination of trends that can be compared with known data from earlier historical research.

A selection of type, considered in the museum as possibly being of sixteenth-century origin, was made. Six groups of type with a total of 28 items were measured using XRF (Figure 4), twice for each item. Ethiopian, Hebrew, Fleuron and music types were selected because they were used within a limited period and it was therefore believed that there was only a small chance that they had been recast later.

The results showed that, in most cases, there was a fair degree of homogeneity within the alloy compositions measured. Each group, as specified by its inventory listing (see Figure 6), resulted in metal concentrations that were very close to each other. Only the type from sets MU 3 and MU 6, attributed to van den Keere, showed relatively large deviations with regard to the antimony and tin contents. As is the case with FL 3-1, 2, also attributed to Van 
XRF spectrum on a Pb-Sb-Sn 76-16-8 w\% alloy

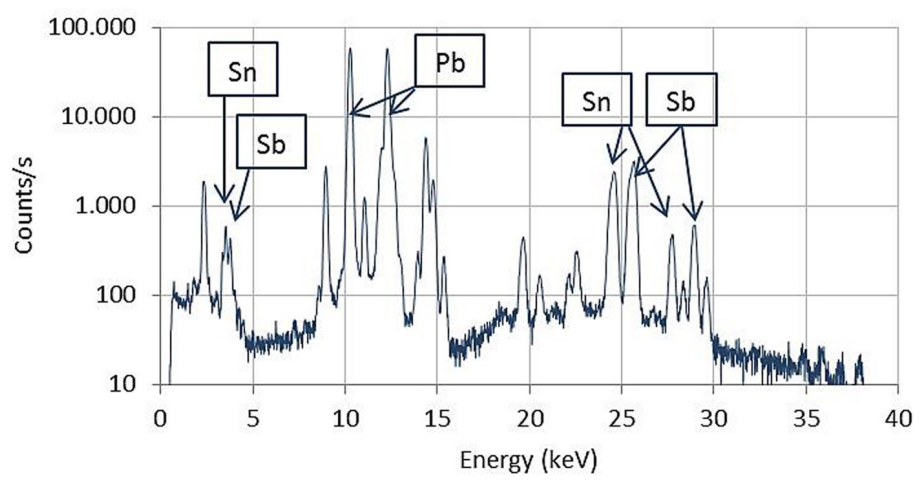

Figure 5: XRF spectrum with the indication of specific lines for lead $(\mathrm{Pb})$, tin $(\mathrm{Sn})$ and antimony $(\mathrm{Sb})$. The $\mathrm{X}$-axis shows the energy of the $\mathrm{X}$-ray beam in $\mathrm{keV}$, the $\mathrm{Y}$-axis shows the counts per second on a logarithmic scale, and radiation detected from each element present in the alloy.

den Keere, they have very low tin concentrations. Nonetheless, Van den Keere also produced cast type, and there is no evidence to attribute these types as they may have been cast in later periods. In this respect, another observation has been made about FL3-2, namely that was finished with extreme accuracy just as was FL3-1, but it even shows the radial lines of a planing machine with such an accuracy that it has to be estimated to be at least a nineteenth-century work. Based on this, the alloy containing a high amount of antimony and a low tin concentration is coherent. A similar conclusion could be drawn concerning MU 3 and MU 6, which might be later recasts as these music types were used well into the seventeenth century. The matrices for these faces also still appeared in the Octavo Inventory of $1652.3^{\circ}$ Group MU 9, however, shows a much higher tin content, together with an elevated copper presence.

High to extremely high concentrations of tin and copper and low concentrations of antimony were found in groups $\mathrm{H}_{2}$ and $\mathrm{FL}_{3-4,5}$, both attributed to Granjon. ${ }^{31}$ Special attention can be drawn to these last two type pieces. There are no punches in the Plantinian collection and the matrices were traded or lost at some point. As neither Granjon nor Plantin cast lead type themselves, it is possible that these lead types were acquired from a type caster and may date from the sixteenth or seventeenth centuries. The medium-high amount of tin and the low antimony concentrations support this idea.

The variations in the composition of the type, even in type from similar periods, can be explained by several factors such as the melting of older type of imprecisely known composition, the renewing of the melting pots' contents during large casting sessions and the freedom of the caster to adapt the composition (such as by adding tin for a sharper cast of small type).

\section{CORROSION DUE TO ACIDIC ENVIRONMENTS}

As a metal, lead is subject to corrosion, especially in acidic environments. As stated previously, the historical setting of the museum is not a favourable environment in this respect. Similar corrosion processes can be observed in church organs, as the lead pipes also suffer from corrosion due to the evaporation of volatile acids from the oak sections of the instrument. ${ }^{2}$ However, it is known that tin inhibits the corrosion of lead when alloyed with at least $2 \%$ by weight. Recent research has shown that the presence of antimony strongly promotes the corrosion of lead. ${ }^{33}$ This was also recorded in the analysis of the heavily corroded type objects from the PlantinMoretus Museum collection. There, it became clear that type with high levels of antimony and no (or very low amounts) of tin were prone to a severe corrosion process. ${ }^{34}$ It may be reassuring, however, that only a small part of the collection has suffered from this condition; nonetheless, it remains an important issue. No conservation technique can recover a type's face when it has become corroded. Only type with a minimal oxidation layer, still with the shapes of the letters intact, can be kept in this condition. To do so, one can use appropriate preventive measures and/or apply conservation techniques for superficial cleaning, such as electrochemical processes, atmospheric plasma cleaning or other methods. To shield the metal from new corrosion, protective layers or dedicated storage packing and acclimatisation can be used. ${ }^{35}$

Here, a second benefit of the XRF analysis may be significant. Determination of the alloy composition is important to estimate whether a certain type has a greater or a smaller chance of becoming corroded if the conservation conditions are not optimal. Therefore, these analyses serve as a selection tool to preserve the vulnerable section of the type collection in favourable atmospheric conditions in climate-controlled storage room. Type with a higher tin content and a low antimony content could be considered safe for further exhibition in situ.

\section{CONCLUSIONS}

The results of the XRF-measurements of a small selection of the lead type in the Plantin-Moretus Museum collection indicate that the alloy composition varies from tin-rich and low-antimony in the earliest periods to small concentrations of tin and a high content of antimony in the eighteenth and nineteenth centuries. The use of the XRF-analysis technique shows its possibilities within a conservation environment. Further large-scaled experiments are to follow, from which new and complemen- 


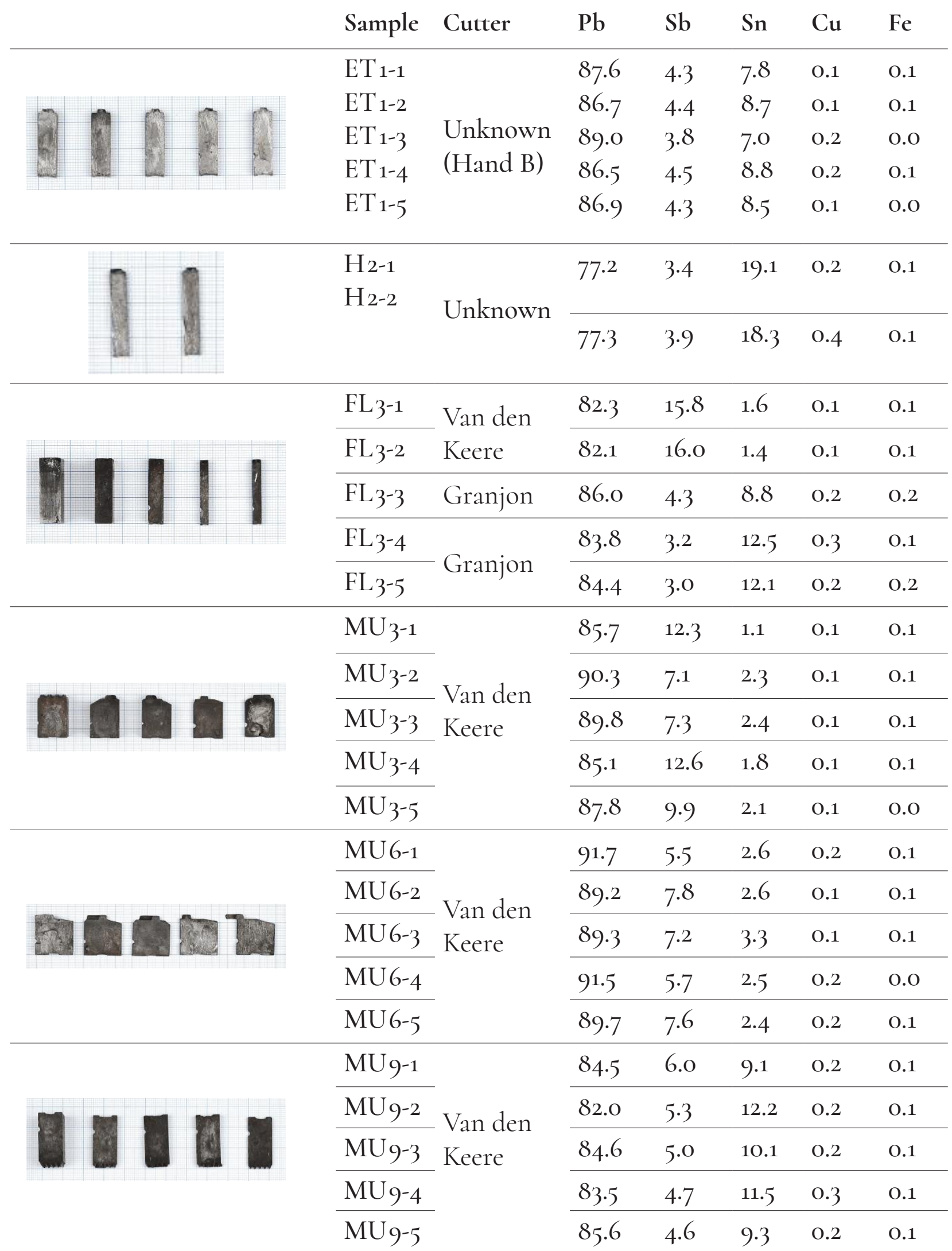

Figure 6: XRF-results for the metals present in the measured alloy (in weight per cent). Photos are to be read starting at No. 1 (e.g. ET 1-1) from left to right (e.g. to ET 1-5). The values, representing weight percent (w\%) of the element in the alloy, are the median of two measurements. The deviation between each two measurements was 0.00-1.74 w\% for Pb (average 0.45 w\%), 0.01-1.74 w\% for $\mathrm{Sb}($ av. $0.23 \mathrm{w} \%)$ and $0.03-1.00 \mathrm{w} \%$ for $S n($ av. $0.24 \mathrm{w} \%)$. 
tary conclusions to earlier historic research might be drawn. In addition to the extensive historical research that has been performed on the collection in the Plantin-Moretus Museum, research on other physical materials, such as the matrices, could offer additional information to confirm former findings, or to question them in some cases. Extensive measurements of the collection can provide insight into the homogeneity and, perhaps, some allocation to certain people or periods. A portable XRFinstrument offers the possibility of analysing a large number of items in a relatively short period. This makes the method highly suitable for elemental measurements of a collection of metal items, such as the one at the Plantin-Moretus Museum, which is composed of many thousands of individual pieces represented by punches, matrices and type. The identification of lead type with a high concentration of antimony and a low tin content necessitates their isolation from acidic environments, which will greatly improve their correct conservation in the future. Moreover, nineteenth-century type in the Plantin-Moretus Museum collection is often acquired, while no punches or matrices are present. Therefore, this lead material is unique, highly valuable and needs to be preserved. The application of non-invasive analytical techniques may offer additional information that enriches the value of this world heritage collection once more.

\section{ACKNOWLEDGEMENTS}

Special thanks are directed to the head and staff of the Museum Plantin-Moretus: Mrs Iris Kockelbergh, Mr Pierre Meulepas and Mr Guy Hutsebaut for their input and kind cooperation. Interesting discussions and useful information were very much appreciated, and were provided by Dr H.D.L. Vervliet, Dr Goran Proot, Dr Pierre Delsaerdt, $\mathrm{Mr}$ Fred Smeijers and $\mathrm{Mr}$ John Lane. I would also like to thank Dr Joost Caen and Dr Karolien De Wael for their continuing support. 


\section{NOTES}

1. Patrick Storme, Marjan Jacobs, Emilie Lieten, "Research on Corrosion of Lead Printing Letters from the Plantin-Moretus Museum," Procedia Chemistry 8 (2013): 307-316.

2. Vlaamse Milieumaatschappij, Lozingen in de lucht 2000-2014 (Aalst, Vlaamse Milieumaatschappij, 2015).

3. B. Krupińska, R. van Grieken and K. De Wael, "Air Quality Monitoring in a Museum for Preventive Conservation: Results of a Three-Year Study in the Plantin-Moretus Museum in Antwerp, Belgium," Microchemical Jounal 110 (2013): 350-360.

4. Harry Carter, A View of Early Typefounding up to the Year 1600 (1969; repr., Oxford: HyphenPress, 2002), 22.

5. K. Köster "Gutenbergs Strassburger Aachenspiegel - Unternehmen von 1438-1440" in Gutenberg-Jahrbuch (1983), 22-44.

6. As described by Nigel Ramsay in "Age of Chivalry. Art in Plantagenet England 1200-1400," Exhibition Catalogue (London: Royal Academy of Arts, 1987), 395-396, cat. 450.

7. H.J.E. van Beuningen, Heilig en profaan: 1000 laatmiddeleeuwse insignes uit de collectie van H.J.E. van Beuningen (Cothen, Netherlands: Stichting Middeleeuwse Religieuze en profane Insignes, 1993). H.J.E. van Beuningen, A.M. Koldeweij and D. Kicken. Heilig en Profaan 2; 1200 Laatmiddeleeuwse insignes uit openbare en particuliere collecties (Cothen, Netherlands: Stichting Middeleeuwse Religieuze en Profane Insignes, 2001). H.J.E. van Beuningen, A.M. Koldeweij, D. Kicken and H. van Asperen. Heilig en Profaan 3; 1300 laatmiddeleeuwse insignes uit openbare en particuliere collecties (Cothen, Netherlands: Stichting Middeleeuwse Religieuze en Profane Insignes, 2012).

8. Van Beuningen, Heilig en profaan, chapter 'Technical Aspects'.

9. J. Moxon, Mechanick Exercises, Vol.I (London: Sign of Atlas, 1683), 147. Fournier, Le Jeune. Manuel typographique. Tome I (Paris: Fournier Le Jeune, 1764), 68 .

10. Vannoccio Biringuccio, translated by C.S. Smith and M.T. Gnudi. De la pirotechnia (New York, USA: Dover Publications, Inc., 1990).

11. Biringuccio, De la pirotechnia, Book I, chapter 2; Ibid., 'On Silver Ore', 48. 12. Biringuccio, De la pirotechnia, 'Introduction'; 'Life of Biringuccio', ix. 13. Fournier, Manuel typographique, 109-124.

14. L. Voet, The Management of a Printing and Publishing House in Renaissance and Baroque. (Amsterdam, Van Gendt \& Co., 1972), 95-96.

15. L. Voet, The History of the House of Plantin-Moretus, Antwerp (Amsterdam, Van Gendt \& Co., 1967), Annex 6, p. 440-445.

16. Voet, The Management, 90-126.

17. Carter, A View on Early Typefounding, 21.

18. Voet, The Management, 96.

19. Ibid., 97 , footnote no. 3 .

20. Fournier, Manuel typographique, 109-111.

21. W. Wilkes, Das Schriftgiessen (Darmstadt: Lehrdruckerei der Technischen Hochschule Darmstadt, 1990).

22. H.J. Bachmann, "Die Schriftgiesserei," in Archiv für Buchdruckerkunst und verwandte Geschäftszzeige, $N^{\circ}$, Bd.4. (Leipzig, 1867). H. Smalian, Practisches Handbuch für Buchdrucker im Verkehr mit Schriftgiessereien (Danzig, 1874).

23. B. Krebs, Handbuch der Buchdruckerkunst (1827; repr., Frankfurt am Main: Boghardt, Janssen and Wilkes, 1983).

24. J. G. Thompson, "Properties of Lead-Bismuth, Lead-Tin, Type Metal, and Fusible Alloys," Bureau of Standards Journal of Research, Vol. 5 (1930): 1085-1107.

25. Thompson, Properties of Lead Alloys, 1096.

26. Moxon, Mechanick Exercises, 169.
27. Fournier, Manuel typographique, 9o.

28. Thompson, Properties of Lead Alloys, 1093.

29. Carter, A View on Early Typefounding, 21. S. Pelgen, "Zur Archäologie der Buchdruckletter," Gutenberg Jahrbuch (1996): 195-205.

3o. Archives of the Plantin-Moretus Museum (Cf. J. Denucé, Inventaire des Archives Plantiniennes, Antwerp, 1926), document no. 154, pp. 1-9.

31. H. D. L. Vervliet "The Combinable Type-Ornaments of Robert Granjon, 1564-1578," Journal of the Printing Society (2015): 55-57.

32. C. Chiavari et al., "Atmospheric Corrosion of Historical Organ Pipes: The Influence of Environment and Materials," Corrosion Science 50 (2008): 2444-2455.

33. G. Ghiara, S. Campodonico, P. Piccardo, C. Martini, P. Storme, and M.M Carnasciali, "MicroRaman Investigation on Corrosion of Pb-Based Alloy Replicas of Letters from the Museum Plantin-Moretus, Antwerp," Journal of Raman Spectroscopy 45 (2014), doi:10.1002/jrs.4592 (2014).

34. Storme et al., "Research on Corrosion", 316.

35. C. Chiavari, C. Martini, G. Poli, and D. Prandstraller. "Conservation of Organ Pipes: Protective Treatments of Lead Exposed to Acetic Acid Vapours," Proceedings of Metal 2004 (Canberra: National Museum of Australia, 2004), 281-293.

\section{BIOGRAPHY}

Patrick Storme graduated in 1982 from the Royal Academy of Fine Arts (Antwerp) with a Master's degree in gold- and silversmithing. He then served a six-year internship reconstructing the thirteenth-century Saint-Gertrudis shrine (Nivelles, Belgium), which was partially destroyed during World War II. During this time, he became interested in historical gold- and silversmithing techniques and in the conservation/restoration of metal objects. In the early 1990s, he co-founded the conservation department at the Royal Academy, where he was responsible for studies in the conservation of metals. He has adapted the courses over the years, teaching the craft and systematically incorporating academic standards. The conservation department was integrated into the new Faculty of Design Sciences at the University of Antwerp in 2013, where he is currently undertaking PhD research. His main approach as a conservator-restorer is to act as an intermediary for the crafts of gold- and silversmithing, and historical and analytical scientific research with an ultimate goal of working in the field of conservation.

\section{KEYWORDS}

- Conservation
- Lead
- Type
- XRF
- Analytical research
- Museum Plantin-Moretus

